\title{
Effects of Short-Term Glucagon Administration on Gluconeogenic Enzymes in the Liver of Midlactation Dairy Cows ${ }^{1}$
}

\author{
E. L. Williams, ${ }^{\star 2}$ S. M. Rodriguez, ${ }^{\star}$ D. C. Beitz, $†$ and S. S. Donkin*3 \\ *Department of Animal Sciences, Purdue University, West Lafayette, IN 47907 \\ †Department of Animal Science, lowa State University, Ames 50010
}

\begin{abstract}
During lactation, the dairy cow experiences an increased demand for glucose to support milk production. Increased glucose demand can be met through increased capacity for gluconeogenesis, increased supply of glucose precursors, or a combination of both processes. Glucagon, a key hormone in glucose homeostasis, acts to promote gluconeogenesis and increase glucose output from liver. The objective of this study was to determine the effect of short-term administration of glucagon on expression of gluconeogenic enzymes in lactating dairy cattle. Sixteen multiparous Holstein cows were selected from the Purdue University Animal Sciences Dairy Research Center herd. Cows were stratified on the basis of milk production and days in milk and randomly assigned to either a saline or glucagon injection group ( $\mathrm{n}=8$ per group). Cows were injected subcutaneously at $-21,-14,-7$, and $0 \mathrm{~h}$ relative to final glucagon and saline injections with either $3.75 \mathrm{mg}$ of lyophilized bovine glucagon $(15 \mathrm{mg} / \mathrm{d})$ dissolved in 60 $\mathrm{mL}$ of $0.15 \mathrm{M} \mathrm{NaCl}$ (pH 10.25) or $60 \mathrm{~mL}$ of $0.15 M$ $\mathrm{NaCl}$. Liver biopsy samples were obtained 1 wk before injection to establish baseline values and at $3 \mathrm{~h}$ after cows received final glucagon and saline injections. Biopsy samples were analyzed for mRNA abundance, enzyme activity, protein abundance, and in vitro measures of gluconeogenesis. Glucagon did not alter pyruvate carboxylase or cytosolic phosphoenolpyruvate carboxykinase (PEPCK) mRNA abundance, enzyme activity, or protein abundance, although there was a tendency for greater mRNA expression with the glucagon treatment (4.69 vs. 6.78 , arbitrary units). Glucagon injections did not change mitochondrial PEPCK mRNA expression. Gluconeogenesis from $2.5 \mathrm{mM}\left[2-{ }^{14} \mathrm{C}\right]$ propi-
\end{abstract}

\footnotetext{
Received March 24, 2005.

Accepted August 21, 2005.

${ }^{1}$ Supported in part by funds from Indiana Agricultural Research Programs as a contribution to North Central Regional project NC1009 and USDA National Research Initiative Competitive Grant 2002-35204-12353.

${ }^{2}$ Current address: 313 Kildee Hall, Iowa State University, Ames 50010.

${ }^{3}$ Corresponding author: sdonkin@purdue.edu
}

onate and $2.0 \mathrm{mM}\left[\mathrm{U}_{-}{ }^{14} \mathrm{C}\right]$ lactate was similar in liver biopsy samples from glucagon-treated and control cows. There was no effect of glucagon on dry matter intake and milk production. Glucose, nonesterified fatty acids, $\beta$-hydroxybutyrate acid, and insulin were not altered by glucagon. Blood glucagon was elevated, 76.09 vs. $96.14 \mathrm{pg} / \mathrm{mL}$, for cows receiving glucagon injections. The data indicate that 24-h administration of glucagon does not alter cytosolic PEPCK mRNA expression or result in immediate alterations in total PEPCK enzyme activity and gluconeogenic capacity.

Key words: gluconeogenesis, gene expression, glucagon

\section{INTRODUCTION}

Gluconeogenesis is critical in the ruminant animal. During lactation, the dairy cow experiences an increased demand for glucose to support milk production (Bell, 1995). Increased glucose demand associated with lactation can be met by increasing the capacity for gluconeogenesis, the supply of glucogenic precursors, or both. The activity of enzymes that are rate-limiting for gluconeogenesis are regulated 1) by hormones, 2) by substrate availability, 3) allosterically, or 4) by a combination of these processes.

Glucagon is a key hormone in glucose homeostasis. The release of glucagon is stimulated by hypoglycemic conditions and is inhibited by hyperglycemia and insulin (Cryer et al., 2003). Glucagon primarily acts on liver, brain, pancreas, kidney, intestine, and adipose tissue (Christophe, 1995; Burcelin et al., 1996). The primary action of glucagon on liver is to promote gluconeogenesis, promote glycogenolysis, and enhance glucose output. Exogenous glucagon serves to increase blood glucose concentrations in ruminants (de Boer et al., 1986; Hippen et al., 1999a). However, there is a lack of information regarding the effects of glucagon on expression of key gluconeogenic enzymes and hepatic glucose production in lactating dairy cows.

Exogenous glucagon in nonruminant liver increases phosphoenolpyruvate carboxykinase (PEPCK) mRNA concentrations (Iynedjian and Hanson, 1977; Beale et al., 1984; Christ et al., 1988) through activation of ade- 
nylate cyclase and targeted transcription of the PEPCK gene. Activity of pyruvate carboxylase (PC), a key enzyme for the metabolism of lactate to glucose, is increased when glucagon is administered to sheep (Brockman and Manns, 1974). A decrease in PEPCK mRNA and a corresponding increase in PC mRNA were noted when midlactation cows were continuously infused with glucagon over a 3.5-h interval (She et al., 1999). The decrease in PEPCK mRNA in that study was surprising, particularly when compared with results reported in nonruminant literature that indicated an acute action of glucagon to increase liver PEPCK mRNA (Beale et al., 1984; Christ et al., 1988). As discussed previously (She et al., 1999), the effects of acute infusion with glucagon may be the result of increased insulin concentration and the opposing actions of insulin with regard to PEPCK mRNA (Beale et al., 1984).

The objective of this study was to determine the effect of glucagon on expression of PC and PEPCK in lactating dairy cattle at the level of mRNA, enzyme activity, protein abundance, and gluconeogenic capacity. Based on the literature, we hypothesized that short-term treatment with glucagon would result in changes in the expression and activity of PC and PEPCK.

\section{MATERIALS AND METHODS}

\section{Experimental Design}

Sixteen multiparous Holstein cows were selected from the Purdue University Dairy Research Center herd. Cows were stratified on the basis of previous milk production and DIM and randomly assigned to either a control or glucagon injection group ( $\mathrm{n}=8$ per group). At the beginning of the experiment, cows were $96 \pm 8$ DIM, weighed $595 \pm 47 \mathrm{~kg}$, had a BCS of $2.50 \pm 0.12$, and were in their third lactation. All experimental procedures involving animals were approved by the Purdue University Animal Care and Use Committee.

\section{Cow Management and Sampling}

All cows were fed a total mixed diet for $10 \%$ orts (Table 1). Cows were fed daily at $0800 \mathrm{~h}$, and feed was always available. To accommodate sample collection, cows were divided into 2 blocks consisting of 4 control and 4 glucagon-treated cows within each block. Each block received the same experimental conditions and sampling protocol but was separated in time by $2 \mathrm{~d}$. The glucagon was a gift from Eli Lilly \& Co. (Indianapolis, IN). Lyophilized bovine glucagon was dissolved before injections in $60 \mathrm{~mL}$ of $0.15 \mathrm{M} \mathrm{NaCl}(\mathrm{pH} 10.25)$. Cows were injected in the neck with $3.75 \mathrm{mg}$ of glucagon in $60 \mathrm{~mL}$ of $0.15 \mathrm{M} \mathrm{NaCl}$ (pH 10.25) at each treatment time. Cows were injected with a total of 4 doses of
Table 1. Diet ingredients and nutrient composition

\begin{tabular}{|c|c|}
\hline Item & $\%$ of $\mathrm{DM}^{1}$ \\
\hline \multicolumn{2}{|l|}{ Ingredient } \\
\hline Corn silage & 50.23 \\
\hline Alfalfa haylage & 22.67 \\
\hline Soybean meal & 5.35 \\
\hline Raw soybeans & 3.70 \\
\hline Soy hulls & 3.24 \\
\hline High-moisture shelled corn & 4.16 \\
\hline Alfalfa hay & 4.63 \\
\hline Fishmeal & 0.23 \\
\hline Megalac Plus $^{2}$ & 0.23 \\
\hline Corn, finely ground & 2.80 \\
\hline PM-42 (42\% dried molasses $)^{3}$ & 0.93 \\
\hline Calcium carbonate & 0.47 \\
\hline Sodium bicarbonate & 0.35 \\
\hline Dicalcium phosphate & 0.28 \\
\hline DCAD Plus (potassium carbonate) ${ }^{2}$ & 0.19 \\
\hline Sodium chloride & 0.17 \\
\hline $\mathrm{XP}$ yeast culture ${ }^{4}$ & 0.10 \\
\hline Animag 5 & 0.10 \\
\hline Dynamate $^{6}$ & 0.04 \\
\hline Nicotinamide (niacin) & 0.02 \\
\hline Trace minerals and vitamins premix ${ }^{7}$ & 0.10 \\
\hline \multicolumn{2}{|l|}{ Chemical composition $^{8}$} \\
\hline $\mathrm{CP}$ & 17.00 \\
\hline $\mathrm{ADF}$ & 23.90 \\
\hline $\mathrm{NDF}$ & 38.70 \\
\hline $\mathrm{NE}_{\mathrm{L}}, \mathrm{Mcal} / \mathrm{kg}$ of $\mathrm{DM}$ & 1.64 \\
\hline $\mathrm{Ca}$ & 1.04 \\
\hline $\mathrm{P}$ & 0.42 \\
\hline \multicolumn{2}{|l|}{${ }^{1}$ Unless otherwise indicated. } \\
\hline \multicolumn{2}{|c|}{${ }^{2}$ Arm \& Hammer (Church \& Dwight, Inc., Princeton, NJ). } \\
\hline \multicolumn{2}{|l|}{${ }^{3}$ American AGCO (St. Paul, MN). } \\
\hline \multicolumn{2}{|l|}{${ }^{4}$ Diamond V Mills, Inc. (Cedar Rapids, IA). } \\
\hline \multirow{2}{*}{\multicolumn{2}{|c|}{$\begin{array}{l}{ }^{5} \text { Prince Agri. Products, Inc. (58\% magnesium oxide) (Quincy, IL). } \\
{ }^{6} \text { International Minerals Corporation, Inc. (Terre Haute, IN). }\end{array}$}} \\
\hline & \\
\hline \multirow{3}{*}{\multicolumn{2}{|c|}{$\begin{array}{l}{ }^{7} \text { Contained } 2.47 \% \mathrm{~S}, 26,720 \mathrm{ppm} \text { of } \mathrm{Zn}, 9,296 \mathrm{ppm} \text { of } \mathrm{Cu}, 23,360 \\
\mathrm{ppm} \text { of } \mathrm{Mn}, 200 \mathrm{ppm} \text { of Se, } 640 \mathrm{ppm} \text { of } \mathrm{Co}, 350 \mathrm{ppm} \text { of I, 3,896 kIU } \\
\text { of vitamin A } / \mathrm{kg}, 1,126 \mathrm{kIU} \text { of vitamin D/kg, and } 18 \mathrm{kIU} \text { of vitamin } \\
\text { E/kg. }\end{array}$}} \\
\hline & \\
\hline & \\
\hline & \\
\hline
\end{tabular}

glucagon over a 21 -h period for a total of $15 \mathrm{mg}$ of glucagon given at $-21,-14,-7$, and $0 \mathrm{~h}$ relative to last injection. Control animals received subcutaneous injections of $60 \mathrm{~mL}$ of $0.15 \mathrm{M} \mathrm{NaCl}(\mathrm{pH} \mathrm{10.25)}$ ) at each of the same time points. Site of injection was alternated from left to right, and animals were observed for any adverse reaction at injection sites.

Cows were housed in individual tie stalls for $14 \mathrm{~d}$ prior to glucagon injections. Individual DMI were determined daily by difference of feed offered and refused and adjusted for feed DM content. Dry matter intake was measured daily beginning $2 \mathrm{wk}$ prior to injections through 1 wk after injections. Feed samples were collected once per week, and a composite sample was analyzed for chemical composition by wet chemistry methods (Dairy One, Ithaca, NY). Cows were milked twice daily, and individual milk yields were determined elec- 
tronically at each milking (HerdMaster Galaxy Management, Alfa-Laval Agri Inc., St. Louis, MO).

Blood samples were obtained by coccygeal veinpuncture. On occasion when samples could not be collected from tail vein, samples were drawn from a jugular vein. All blood samples were collected into evacuated tubes (Becton Dickinson, Rutherford, NJ) immediately prior to glucagon or saline injections at $-21,-14,-7$, and 0 $\mathrm{h}$ relative to final injection. Additional samples were collected at 1.5, 3,15 , and $27 \mathrm{~h}$ relative to final injection. Tubes for NEFA and glucose assays contained sodium fluoride and potassium oxalate. Tubes for glucagon analysis contained $\mathrm{Na}_{2}$-EDTA. Tubes for plasma preparation were put on ice immediately after sampling and centrifuged at $4^{\circ} \mathrm{C}$ at $3,000 \times g$ for 20 min within $1 \mathrm{~h}$ of collection. Samples were stored in borosilicate glass culture tubes (VWR Scientific Products, West Chester, PA) at $-20^{\circ} \mathrm{C}$ until analysis. Prior to storage at $-20^{\circ} \mathrm{C}$, aprotonin (Boehringer-Mannheim, Indianapolis, IN) was added to samples intended for glucagon analysis as recommended by the product manufacturer (Diagnostic Products Corporation, Los Angeles, CA) to inhibit proteolytic degradation in the samples. Samples were analyzed for serum glucose (Glucose C2 Autokit, Wako Fine Chemicals Industries USA, Inc., Dallas, TX), NEFA (NEFA-C, Wako Fine Chemicals Industries USA, Inc.; Johnson and Peters, 1993), and BHBA (Gibbard and Watkins, 1968) in a 96-well microplate format and read on a Packard SpectraCount plate reader (Packard Instrument Co., Meriden, CT). Plasma glucagon and serum insulin were quantified by using radioimmunoassay kits and the human standards supplied (Diagnostic Products Corporation). The intraassay coefficient of variation for glucagon was $0.04 \%$, and the interassay variation was $14 \%$. For insulin, the intraassay coefficient of variation was $0.16 \%$, and the interassay variation was $8.6 \%$.

Liver biopsy samples (3 $\mathrm{g}$ total) were obtained by percutaneous needle biopsy (Greenfield et al., 2000) at $7 \mathrm{~d}$ prior to the start of injections and at $3 \mathrm{~h}$ after the last glucagon or saline injections. Liver samples were rinsed in saline, and $1 \mathrm{~g}$ of sample was placed in a tube containing $10 \mathrm{~mL}$ of guanidinium thiocyanate solution [4 $M$ guanidinium thiocyanate, $25 \mathrm{~m} M$ sodium citrate (pH 7.4), 0.5\% sarcosyl, and 0.1 $M \beta$-mercaptoethanol], snap-frozen in liquid nitrogen, and placed in a $-80^{\circ} \mathrm{C}$ freezer until analysis. A second aliquot $(1 \mathrm{~g})$ was rinsed in PBS, snap-frozen in liquid nitrogen, and placed in a $-80^{\circ} \mathrm{C}$ freezer pending analysis by Western blotting. Samples for PC and PEPCK enzyme activity assay (0.4 $\mathrm{g})$ were rinsed in saline, snap-frozen in liquid nitrogen, and stored at $-80^{\circ} \mathrm{C}$. An additional aliquot $(0.6 \mathrm{~g})$ for in vitro incubation was rinsed in saline and placed in a $50-\mathrm{mL}$ conical tube containing $10 \mathrm{~mL}$ of Dulbecco's
Modified Eagles Media (DMEM) and 1\% BSA, placed on ice, and transported to the laboratory.

\section{cDNA Probe, RNA Extraction, and Northern Analysis}

Plasmids bPC1000, containing a 1,051-bp fragment of bovine PC cDNA, and bPEPCK-700, containing a 1,150-bp fragment of bovine PEPCK-C cDNA, were cloned in our laboratory (Agca et al., 2002). The cDNA probe for PEPCK-M was also cloned in our laboratory and was generated by digestion of bPEPCK-M at an internal HindII site (Agca et al., 2002). Insert DNA was removed from plasmids by restriction enzyme digestion. Insert was separated by electrophoresis through a $1 \%$ agarose gel and purified by using the Wizard DNA Purification system (Promega, Madison, WI). Gamma${ }^{32} \mathrm{P}$ [dCTP] and Ready-to-go DNA labeling kit (Pharmacia, Piscataway, NY) were used to generate the radiolabelled cDNA probes. The specific activity of cDNA probes was approximately $10^{9} \mathrm{cpm} / \mu \mathrm{g}$ of DNA.

Total RNA was extracted from liver biopsy samples as previously described (Chomczynski and Sacchi, 1987). A $20-\mu \mathrm{g}$ aliquot was separated through a $1 \%$ agarose gel and transferred to a Genescreen membrane (NEN Life Science Products, Boston, MA). Transfer occurred for $20 \mathrm{~h}$ before RNA was cross-linked using UV light. Membrane was baked for $2 \mathrm{~h}$ at $80^{\circ} \mathrm{C}$ to remove any residual formaldehyde.

Membranes were prehybridized for $15 \mathrm{~h}$ at $42^{\circ} \mathrm{C}$ in a prehybridization solution consisting of $10 \%$ dextran sulfate, $5 \times \mathrm{SSPE}\left(0.75 M \mathrm{NaCl}, 0.05 M \mathrm{NaH}_{2} \mathrm{PO}_{4} \cdot \mathrm{H}_{2} \mathrm{O}\right.$, and $5 \mathrm{~m} M$ EDTA), $50 \%$ deionized formamide, $5 \times$ Denhardt's $(0.1 \%$ Ficoll, $0.1 \%$ polyvinylpyrrolidone, and $0.1 \% \mathrm{BSA}$ ), $1 \% \mathrm{SDS}$, and $200 \mu \mathrm{g}$ of denatured herring sperm DNA $/ \mathrm{mL}$ ). Hybridization with the ${ }^{32} \mathrm{P}$-labeled cDNA probes occurred for $18 \mathrm{~h}$ at $42^{\circ} \mathrm{C}$. Membranes were then washed twice with $2 \times$ sodium chloride/sodium citrate (SSC; $0.3 M \mathrm{NaCl}, 0.03 M$ sodium citrate, $\mathrm{pH}$ 7.0) at room temperature for $5 \mathrm{~min}$, twice with $1 \times$ $\mathrm{SSC}, 1 \% \mathrm{SDS}$ at $65^{\circ} \mathrm{C}$ for $30 \mathrm{~min}$, and twice in $0.1 \times \mathrm{SSC}$ (0.015 $M$ NaCl, $0.0015 M$ sodium citrate, $\mathrm{pH} 7.0)$ at room temperature for $30 \mathrm{~min}$.

Kodak X-Omat AR film was used to visualize the mRNA transcripts. Expression was quantified by using Kodak Digital Science 1-D Image Analysis software (Eastman Kodak Co., Rochester, NY). Pooled samples of bovine liver mRNA were placed on the outside lanes of gel to account for variation in transfer of RNA, hybridization, and washing. Variation in loading between samples was adjusted using 18S mRNA abundance.

\section{Protein Extraction and Immunoblots}

Liver tissue ( $1 \mathrm{~g}$ ) was thawed and minced on ice with scissors in PBS. To the minced tissue on ice, $5 \mathrm{~mL}$ of 
protein extraction buffer $(20 \mathrm{~m} M$ Tris $\cdot \mathrm{HCl}(\mathrm{pH}$ 7.4), 10 $\mathrm{m} M \mathrm{NaCl}, 10 \mathrm{~m} M \mathrm{KCl}, 3 \mathrm{~m} M \mathrm{MgCl}_{2}$, and $1 \mathrm{mg}$ of Protease Inhibitor Cocktail/mL (Sigma, St. Louis, MO) was added and homogenized for 1 min using a Polytron homogenizer. Nonidet P-40 was added to $0.5 \%$, and the homogenate was shaken in ice for $15 \mathrm{~min}$ and homogenized again using a Douce homogenizer. Homogenate was centrifuged at $10,000 \times g$ for $15 \mathrm{~min}$. The supernatant was removed, frozen in liquid nitrogen, and placed in $-80^{\circ} \mathrm{C}$ freezer until quantification. Protein was quantified by using the BCA Protein Assay Reagent Kit (Pierce, Rockford, IL).

Liver protein samples were incubated at $60^{\circ} \mathrm{C}$ and separated (15 $\mu \mathrm{g}$ of protein per lane) by $7.5 \%$ SDS polyacrylamide gel electrophoresis (Laemmli, 1970). Purified bovine liver PC (Sigma-Aldrich) also was included in a separate lane in the gel. The separated proteins were electrotransferred to $0.45-\mu \mathrm{m}$ pure nitrocellulose membrane, and protein bands were visualized by fastgreen staining.

For analysis of biotin-dependent proteins, the membrane was blocked by incubation for $5 \mathrm{~min}$ in TBS/ Tween buffer ( $30 \mathrm{~m} M$ Tris base, $300 \mathrm{~m} M \mathrm{NaCl}$, and 1 $\mathrm{mL}$ of Tween 20/L, $\mathrm{pH}$ 7.5) and for $1 \mathrm{~h}$ in blocking solution (30 mM Tris base, $300 \mathrm{~m} M \mathrm{NaCl}, 1 \mathrm{~mL}$ of Tween 20/L, and 1.75\% BSA, pH 7.5). The membrane was incubated for $1 \mathrm{~h}$ in blocking solution with $1.75 \%$ BSA containing an anti-biotin antibody (monoclonal anti-biotin clone, BN-34, horseradish peroxidase-conjugate; 1:6,000 dilution; Sigma-Aldrich). The membrane was washed 5 times for 5 min each in blocking solution and for $10 \mathrm{~min}$ in TBS/Tween. Membranes were blotted gently to remove excess moisture, and a chemiluminescent substrate (Pierce Supersignal chemiluminescent substrate, Rockford, IL) was applied for $5 \mathrm{~min}$. The membranes were blotted gently, wrapped in plastic wrap, and exposed to x-ray film (Kodak X-Omat AR).

\section{Determination of Molecular Size and Relative Protein Abundance}

Digital images of the autoradiographic film from the immunoblots were scanned, and scanning densitometry was performed with the Kodak Digital Science 1-D Image Analysis Software (Eastman Kodak Co.) Relative molecular weights of biotin-dependent proteins were calculated by regressing the distance of migration of the protein through the gel, against the relative molecular weights of known markers, ranging from 9.1 to 184.5 $\mathrm{kDa}$ (Benchmark Prestained Protein Ladder, Invitrogen Corp., Carlsbad, CA).

\section{Assay for PC and PEPCK Activity}

Liver biopsy samples were thawed on ice, blotted dry, and weighed. Crude tissue extracts were prepared by homogenizing tissue in 3 volumes of ice-cold $0.1 M$ sucrose, $50 \mathrm{~m} M$ potassium phosphate ( $\mathrm{pH} 7.4$ ), and 0.25 $\mathrm{m} M$ EDTA (pH 7.4) with a Tissuemizer (Tekmar Inc., Cincinnati, OH). Samples were sonicated with a probe sonicator (Ultrasonics Inc., Plainview, NY) for $30 \mathrm{~s}$ to disrupt mitochondria and then centrifuged for $15 \mathrm{~min}$ at $600 \times g$ to remove cell debris. Supernatant was removed and assayed for PC (Greenfield et al., 2000) and PEPCK (Agca et al., 2002) activities.

\section{Preparation of Liver Slices and Measures of Gluconeogenesis}

Liver biopsy samples were transported to the laboratory in ice-cold DMEM containing 1\% BSA. Within 40 min of removal from the animal, the biopsy core samples were sliced using a razor blade into 3 - to 4 -mm uniform sections weighing 30 to $50 \mathrm{mg}$, and slices for each cow were incubated in DMEM containing $1 \%$ BSA and 2.5 $\mathrm{m} M$ propionate, $1.0 \mathrm{~m} M$ pyruvate, $1.0 \mathrm{~m} M$ lactate, and $2.0 \mathrm{~m} M$ glycerol as outlined previously for bovine hepatocytes (Donkin and Armentano, 1993). The metabolism of $\left[2-{ }^{14} \mathrm{C}\right]$ propionate and $\left[\mathrm{U}-{ }^{14} \mathrm{C}\right]$ lactate to glucose was determined over a 2-h interval as previously described (Donkin and Armentano, 1993). Measurements were performed in triplicate for $2 \mathrm{~h}$. Incubations were terminated by the addition of $0.5 \mathrm{~mL}$ of $5 \mathrm{~N} \mathrm{H}_{2} \mathrm{SO}_{4}$ to the media. The conversion of radiolabelled precursor to glucose was determined in the media as described previously (Donkin and Armentano, 1993). The rates of gluconeogenesis were calculated from the specific radioactivity of the precursor and nanomoles of product formed per hour. Rates of gluconeogenesis are expressed as nanomoles of precursor converted to glucose/ milligram of liver per hour.

\section{Statistical Analyses}

The data were analyzed by using the PROC Mixed analysis of SAS (SAS Institute, 1988). For repeated measurements, the model included the fixed effects of block, treatment, and time relative to the last glucagon injection, random effects of cow within treatment by time, the interactions of fixed effects, and the residual error. The covariance structure was determined for anti-dependence, simple, unstructured, and autoregressive models. The model that yielded the minimal range of values for Akaike information criterion and Bayesian information criterion (BIC) for each variable was used for data analysis. First-order ante-dependence structure gave the lowest BIC coefficient for milk production, NEFA concentration, and BHBA concentration. Compound symmetry gave the lowest BIC coefficient for DMI, glucose, insulin, and glucagon concentra- 
tions. Liver samples obtained at $1 \mathrm{wk}$ before glucagon injections served as a covariate in the analysis of PC, cytosolic PEPCK (PEPCK-C), and mitochondrial (PEPCK-M) mRNA abundance. If the effect of block was not significant, it was eliminated from the model. Means differed if $P<0.05$ and tended to differ if 0.05 $\leq P \leq 0.15$. The values reported are least squares means and standard errors unless noted otherwise. The relationships among mRNA expression, enzyme activity, protein abundance, and the in vitro incubation assay were examined. Pearson correlation coefficients were obtained using the PROC CORR procedure of SAS (SAS Institute, 1988).

\section{RESULTS AND DISCUSSION}

Glucagon treatment did not affect DMI (Figure 1; Table 2). An effect of day relative to final injection, however, was observed $(P<0.05)$. Dry matter intake was significantly decreased on the day of liver biopsy and during the 24-h glucagon injection period leading up to the biopsy for both glucagon- and saline-treated cows. The depression in DMI is a likely consequence of the increased frequency with which cows were handled because of repetitive subcutaneous injections over a 24$\mathrm{h}$ period, as there was no differences in DMI for glucagon vs. saline cows. Previous studies have indicted a lack of effect of biopsy on DMI (Vazquez-Anon et al., 1994). Milk production did not differ between glucagonand saline-treated animals (Figure 1; Table 2). This observation is in agreement with the literature, which describes a lack of relationship between glucagon injections and milk yield (Hippen et al., 1999b; Bobe et al., 2003a).

Plasma glucagon concentrations tended to be greater for cows receiving glucagon when all samples were analyzed ( $P<0.10$; Figure 2; Table 3 ). Glucagon concentrations for samples taken at $1.5 \mathrm{~h}$ after the final glucagon injection were 59\% greater for cows receiving the glucagon injections compared with those for the salinetreated cows (149 vs. $89 \mathrm{pg} / \mathrm{mL} ; P<0.10)$. The value obtained for cows receiving saline injections is approximately equal to the level previously observed for midlactation dairy cattle (She et al., 1999). In lactating dairy cows, blood glucagon concentration is elevated by exogenous glucagon treatment (Hippen et al., 1999a,b; She et al., 1999; Bobe et al., 2003b). Plasma insulin concentrations were not altered by glucagon injections (Figure 2; Table 3). Several studies support an increase in insulin concentration when dairy cattle receive exogenous glucagon (Hippen et al., 1999a; She et al., 1999; Bobe et al., 2003a). The exception is a study reported by Hippen et al. (1999b), who observed that blood insulin

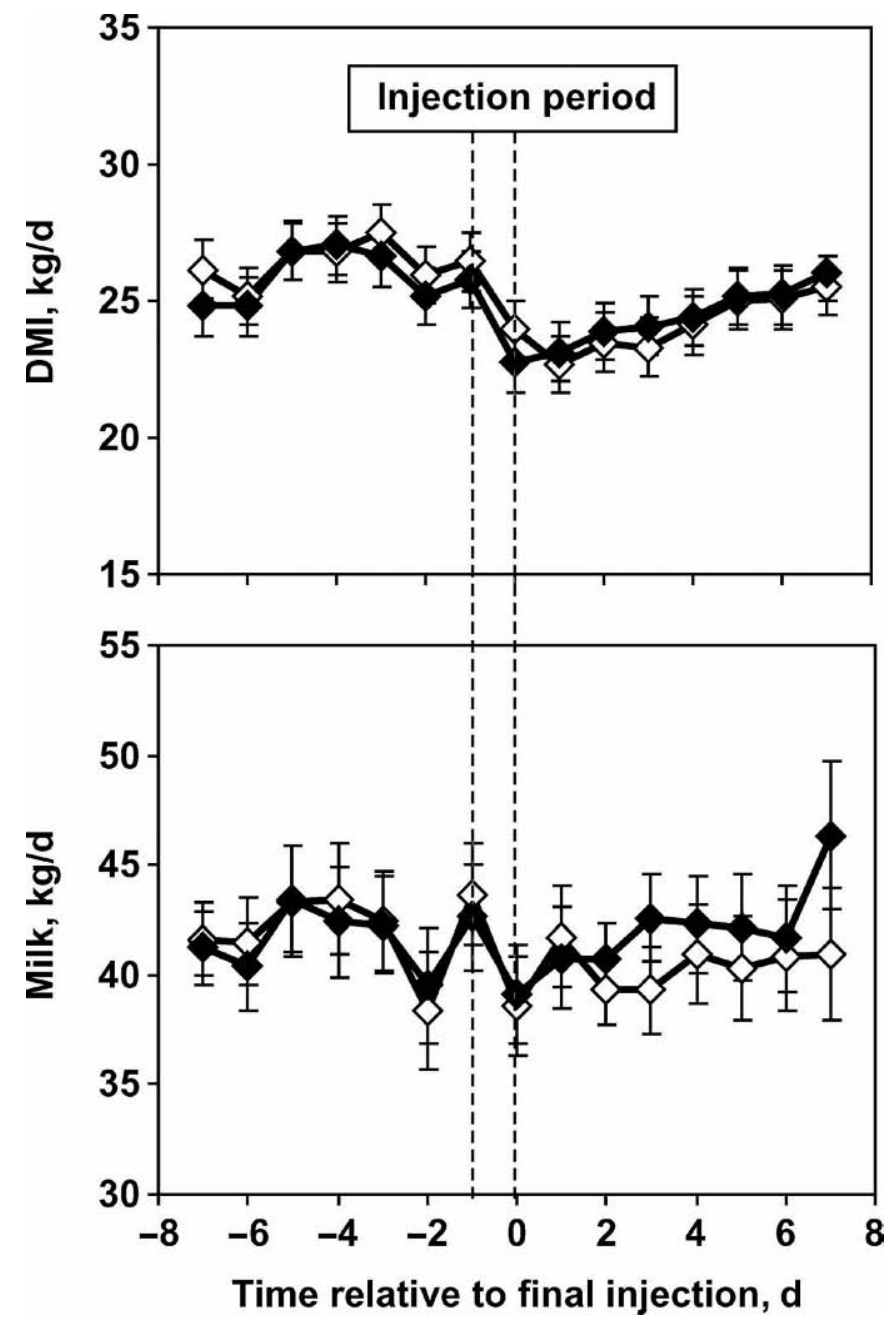

Figure 1. Effect of glucagon $(\diamond)$ or saline injections $(\diamond)$ on DMI (upper panel) and milk production (lower panel). Glucagon or saline injections were administered during the period indicated, and liver biopsy samples were obtained on $\mathrm{d}-7$ and within $+3 \mathrm{~h}$ after the final injection. Data are least squares means and standard errors. There was an effect of time on both measures $(P<0.05)$, and no effect of glucagon $(P>0.05)$ or glucagon $\times$ time $(P>0.05)$.

concentrations were unchanged in response to glucagon infusions of $10.0 \mathrm{mg} / \mathrm{d}$ for $14 \mathrm{~d}$.

Glucagon treatment did not alter blood glucose, NEFA, or BHBA concentrations (Table 3). Glucagonand saline-treated cows had elevated glucose concentrations at $1.5 \mathrm{~h}$ relative to final injection compared with blood glucose concentrations at $0 \mathrm{~h}(P<0.05)$. During glucagon treatment, blood glucose concentrations typically increase, then rapidly decline to pretreatment values when glucagon treatment is terminated (Hippen et al., 1999a; She et al., 1999). Given the acute effects of glucagon treatment on glucose concentration (She et al., 1999; Bobe et al., 2003b), blood samples taken within 3 $\mathrm{h}$ of a glucagon injection are the best indication of the 
WILLIAMS ET AL.

Table 2. Effect of glucagon administration on DMI and milk production in midlactation dairy cows ${ }^{1}$

\begin{tabular}{|c|c|c|c|c|c|c|}
\hline \multirow[b]{2}{*}{ Measure $^{2}$} & \multicolumn{2}{|c|}{ Treatment } & \multirow[b]{2}{*}{ SEM } & \multicolumn{3}{|c|}{$P$} \\
\hline & Saline & Glucagon & & $\operatorname{Trt}^{3}$ & $\mathrm{TRTF}^{4}$ & $\operatorname{Trt} \times \mathrm{TRTF}^{5}$ \\
\hline DMI, kg/d & 25.22 & 24.86 & 1.02 & NS & $P<0.05$ & NS \\
\hline Milk production, kg/d & 41.10 & 41.84 & 1.40 & NS & $P<0.05$ & NS \\
\hline \multirow{2}{*}{\multicolumn{7}{|c|}{$\begin{array}{l}{ }^{1} \text { Sixteen cows were injected subcutaneously at }-21,-14,-7 \text {, and } 0 \mathrm{~h} \text { with either } 3.75 \mathrm{mg} \text { of bovine glucagon } \\
15 \mathrm{mg} / \mathrm{d} \text { ) or saline. }\end{array}$}} \\
\hline & & & & & & \\
\hline \multicolumn{7}{|c|}{${ }^{2}$ Dry matter intakes and milk production were determined daily for 1 wk prior to injections through 1} \\
\hline \multirow{2}{*}{\multicolumn{7}{|c|}{$\begin{array}{l}{ }^{3} \text { Trt }=\text { Treatment effect (glucagon vs. saline). } \\
{ }^{4} \mathrm{TRTF}=\text { Time relative to final injection effect. }\end{array}$}} \\
\hline & & & & & & \\
\hline Treatment & to & & & & & \\
\hline
\end{tabular}

effects of glucagon on blood glucose. Three hours after the final glucagon and saline injections, both glucagonand saline-treated cows exhibited elevated NEFA concentrations $(P<0.05$; Figure 3). Exogenous glucagon does not affect NEFA concentrations when administered by short-term infusions (Hippen et al., 1999a; She et al., 1999). A decrease in NEFA concentrations was observed $4 \mathrm{~h}$ after subcutaneous injection, and an increase was observed at $8 \mathrm{~h}$ when midlactating cows were given $5 \mathrm{mg}$ of glucagon (Bobe et al., 2003b). At 15 and $27 \mathrm{~h}$ after the final injection, BHBA concentrations were significantly elevated (Figure $3 ; P<0.05$ ), which may be associated with the elevated NEFA concentrations during the injection period. Overall, BHBA concentrations are not affected by exogenous glucagon treatment in dairy cattle (Hippen et al., 1999a; She et al., 1999).

Phosphoenolpyruvate carboxykinase catalyzes the first committed step in gluconeogenesis during the conversion of oxaloacetate to phosphoenolpyruvate. In the dairy cow, 2 isoforms of the enzyme exist and are compartmentalized to the mitochondria (PEPCK-M) and the cytosol (PEPCK-C). For all mammalian species, the isoforms are of the same molecular weight, have similar kinetic properties, but are encoded by separate genes (Hanson and Patel, 1994; Agca et al., 2002). There was no effect of glucagon on PEPCK-C mRNA in samples taken $3 \mathrm{~h}$ after the final glucagon and saline injections. These data are in contrast to previous experiments indicating a decrease in PEPCK with glucagon infusions (She et al., 1999) when midlactation Holstein cows were continuously infused with glucagon for $3.5 \mathrm{~h}(14 \mathrm{mg} / \mathrm{d})$. Those researchers suggested that a rapid increase in blood insulin concentrations inhibited expression of the PEPCK gene. Insulin concentrations were not altered by glucagon in the present experiment, and glucagontreated cows experienced a tendency for increased PEPCK-C mRNA expression $(6.78$ vs. $4.69 ; P<0.15$, Table 4). The present data indicate that PEPCK-C is not responsive to glucagon when given over a 24 -h period despite a lack of change in insulin concentrations. Taken together, these data may indicate that PEPCK$\mathrm{C}$ is not responsive in midlactation cows, but a change in insulin concentrations in response to glucagon injections may be dominant to any response to glucagon. Controlled studies have not been performed to determine the effects of insulin on PEPCK mRNA in cattle.

Although limited research has focused on the role of glucagon on gluconeogenic enzymes in ruminants, the effects in the nonruminant animal have been studied extensively. Glucagon stimulates PEPCK gene expression through the activation of adenylate cyclase activity and cAMP (Jiang and Zhang, 2003). The PEPCK-C gene contains a cAMP response element in its promoter region (Hanson and Reshef, 1997) that binds a cAMP response element binding protein to accelerate PEPCKC transcription (Liu et al., 1991). Treatment of rat liver or rat hepatocytes with exogenous glucagon increases PEPCK mRNA (Iynedjian et al., 1977; Beale et al., 1984; Christ et al., 1988). The PEPCK-C gene is negatively regulated by insulin but induced by glucocorticoids, thyroid hormones, and glucagons (Hanson and Reshef, 1997). In the present experiment, we have extended the delivery of glucagon over a longer interval of time and avoided a corresponding increase in insulin concentrations. Similarly, we did not observe a reduction in PEPCK mRNA expression.

A single subcutaneous injection of either 2.5 or 5 $\mathrm{mg}$ of glucagon in midlactation cows resulted in blood glucagon concentrations that reached approximately 450 and $950 \mathrm{pg} / \mathrm{mL}$, respectively, within $1 \mathrm{~h}$ (Bobe et al., 2003b). Continuous infusion of $10 \mathrm{mg}$ of glucagon over $24 \mathrm{~h}$ via jugular catheter increased glucagon concentrations to $650 \mathrm{pg} / \mathrm{mL}$ (She et al., 1999). The maximal concentrations of glucagon observed in those experiments are approximately 4 to 7 times glucagon concentrations for a midlactation dairy cows. Glucagon concentrations returned to pretreatment levels within $2 \mathrm{~h}$ after the end of intravenous administration (Bobe et al., 2003b) and within 5 to $6 \mathrm{~h}$ after a single subcuta- 


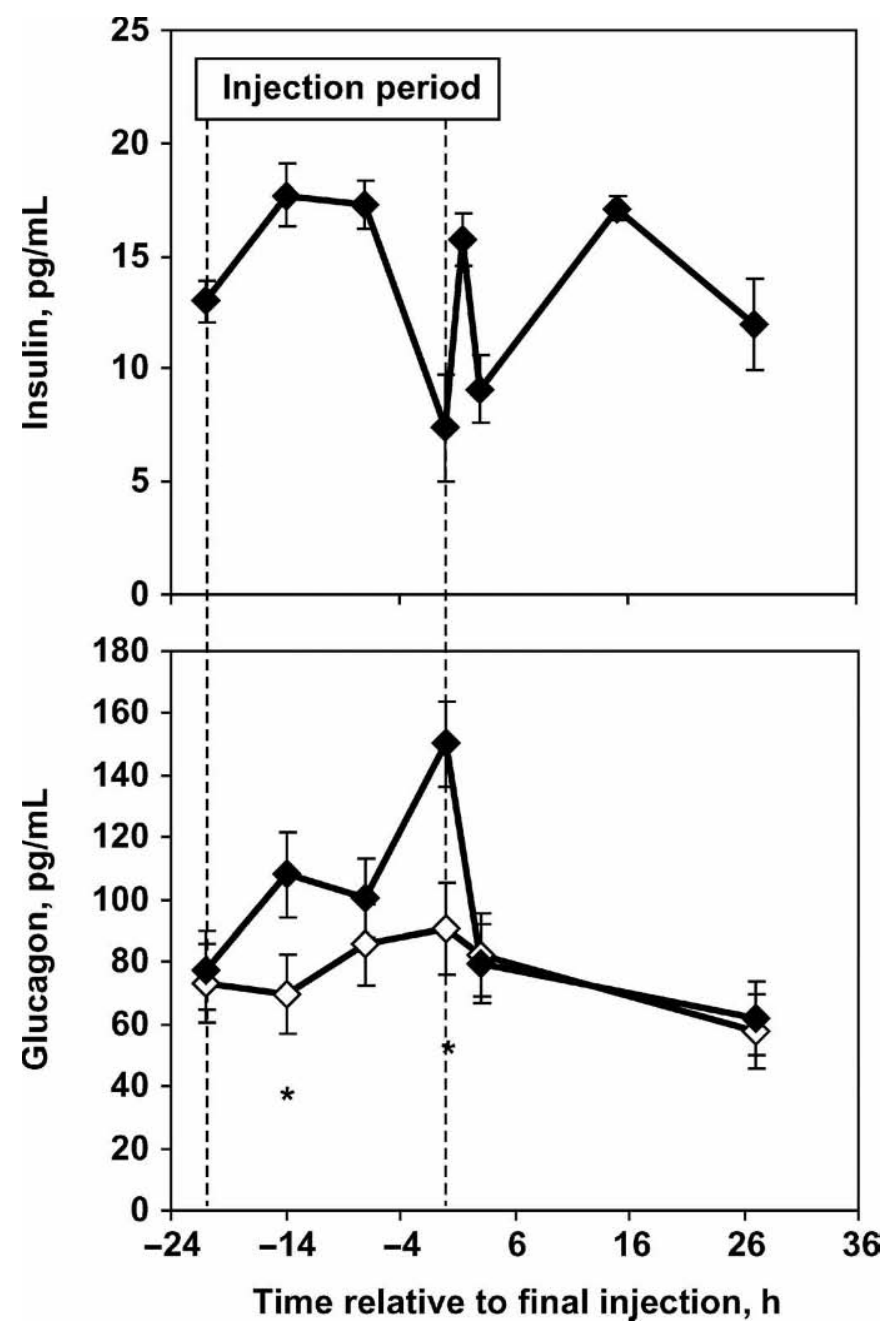

Figure 2. Plasma insulin (upper panel) and glucagon (lower panel) for cows treated with saline or glucagon. Cows were injected subcutaneously with glucagon or saline at $-21,-14,-7$, and $0 \mathrm{~h}$. Blood samples obtained at $-21,-14,-7,0,3$, and $27 \mathrm{~h}$ relative to final injections were analyzed for insulin and glucagon concentration. There was no effect of glucagon on plasma insulin $(P>0.05)$. Therefore, combined data for both groups are presented. There was a main effect of time $(P<0.05)$ and treatment $(P<0.05)$ on plasma glucagon $(P<0.05)$. Glucagon injections increased $(P<0.10)$ plasma glucagon in a timedependent manner (treatment $\times$ time, $P<0.10$ ) compared with controls. The asterisks denote differences in plasma glucagon between cows injected with glucagon $(\diamond)$ or saline $(\diamond)$.

neous injection (She et al., 1999). The 15-mg dose of glucagon given as $3.75 \mathrm{mg}$ every $7 \mathrm{~h}$ in the present experiment would be expected to elicit an increase in blood glucagons, which should dissipate by 5 to $6 \mathrm{~h}$ postinjection. This is reflected by the lack a striking difference in plasma glucagon between control and glucagons-treated cows. The shortest sampling time in the present experiment, $3 \mathrm{~h}$ after the last glucagon injection, resulted in a $1.7 \times$ greater concentration of glucagon compared with either control or baseline values
(Figure 2), which similar is in magnitude to the increase in plasma glucagon observed 2 to $3 \mathrm{~h}$ after a single glucagon injection (Bobe et al., 2003b).

Glucagon treatment did not alter PEPCK-M mRNA expression when compared with the saline control (1.49 vs. 1.02; Table 4). Unlike the cytosolic isoform, PEPCK$\mathrm{M}$ does not respond to hormones (Savon et al., 1993). During the transition to lactation in dairy cows, PEPCK-M transcript expression remains unchanged (Agca et al., 2002). However, it is important to quantify PEPCK-M gene expression, because this enzyme may be responsible for $>50 \%$ of the glucose synthesized in ruminant hepatocytes (Aiello and Armentano, 1987), especially in gluconeogenesis from lactate.

Glucagon injections did not alter PC mRNA expression ( 0.62 vs. 0.98 ; Table 4 ). Liver biopsy samples taken $1 \mathrm{wk}$ before glucagon injections served as the covariate. There was no effect of covariate on PC mRNA expression. Pyruvate carboxylase is responsible for the conversion of pyruvate to oxaloacetate. Our data indicate a lack of effect of glucagon on PC mRNA expression. Previous data (She et al., 1999) indicated that PC mRNA expression increased 1.5 -fold during a 3.5 -h glucagon infusion and remained elevated up to $3.5 \mathrm{~h}$ postinfusion. The methods of glucagon administration differ between the present and previous study (She et al., 1999). In the latter, glucagon was infused intravenously over a 3.5-h period, but, in the present study, glucagon was injected subcutaneously as 4 injections over a 21 -h period. In humans, continuous exposure to glucagon decreases its ability to stimulate hepatic glucose output (Rizza and Gerich, 1979). In vitro studies in rats indicate that the response in blood glucose to glucagon was equivalent for pulsatile administration of glucagon compared with continuous infusion of glucagon. The dose of glucagon required to elicit the observed response, however, was much greater when administered continuously (Komjati et al., 1986). To date, the exact mechanism by which glucagon influences PC gene expression is not well understood, but evidently, the timing and duration of exposure are critical. Data from the current study do not support an effect of glucagon exposure on PC expression, but continuous infusion data supports increased PC mRNA with glucagon (She et al., 1999). Additional work is necessary to determine the direct action of glucagon on PC expression in bovine liver.

Moreover, the failure of glucagon to increase PC activity (Table 4) corroborates the lack of glucagon effect on PC mRNA expression but is at odds with other data in ruminants, indicating an increase in PC activity with glucagon (Brockman and Manns, 1974). Glucagon treatment also did not influence PEPCK enzyme activity (Table 4). The PEPCK activity assay used here does 
WILLIAMS ET AL.

Table 3. Effect of glucagon administration on blood metabolites of midlactation dairy cows ${ }^{1}$

\begin{tabular}{|c|c|c|c|c|c|c|}
\hline \multirow[b]{2}{*}{ Measure $^{2}$} & \multicolumn{2}{|c|}{ Treatment } & \multirow[b]{2}{*}{ SEM } & \multicolumn{3}{|c|}{$P$} \\
\hline & Saline & Glucagon & & $\operatorname{Trt}^{3}$ & $\mathrm{TRTF}^{4}$ & $\operatorname{Trt} \times \mathrm{TRTF}^{5}$ \\
\hline $\mathrm{NEFA}, \mu \mathrm{mol} / \mathrm{L}$ & 124.5 & 128.4 & 11.9 & NS & $<0.05$ & NS \\
\hline Glucose, mg/dL & 61.62 & 62.78 & 1.51 & NS & $<0.05$ & NS \\
\hline BHBA, mg/dL & 9.92 & 8.86 & 1.90 & NS & $<0.05$ & NS \\
\hline Glucagon, pg/mL & 76.09 & 96.14 & 8.16 & $<0.10$ & $<0.05$ & $<0.10$ \\
\hline Insulin, $\mu \mathrm{IU} / \mathrm{mL}$ & 13.35 & 14.04 & 1.96 & NS & $<0.05$ & NS \\
\hline \multicolumn{7}{|c|}{$\begin{array}{l}{ }^{1} \text { Cows were injected subcutaneously at }-21,-14,-7 \text {, and } 0 \mathrm{~h} \text { with either } 3.75 \mathrm{mg} \text { of bovine glucagon }(15 \\
\mathrm{ng} / \mathrm{d}) \text { or saline ( } \mathrm{n}=8 \text { per group). }\end{array}$} \\
\hline \multicolumn{7}{|c|}{$\begin{array}{l}{ }^{2} \text { Blood samples collected at }-21,-14,-7,0,1.5,3,15 \text {, and } 27 \mathrm{~h} \text { relative to final injection. The data are } \\
\text { verall means for saline and glucagons. }\end{array}$} \\
\hline \multirow{2}{*}{\multicolumn{7}{|c|}{${ }^{3}$ Trt $=$ Treatment effect (glucagon vs. saline) }} \\
\hline${ }^{4} \mathrm{TRTF}=$ Time $\mathrm{r}$ & & & & & & \\
\hline . & & & & & & \\
\hline
\end{tabular}

not differentiate between the cytosolic and mitochondrial isoforms; however, a close relationship exists between total PEPCK activity and PEPCK-C mRNA (Hartwell et al., 1999). Despite a trend toward increased PEPCK-C mRNA expression, an increase in PEPCK activity was not observed. In hepatocytes, an increase in PEPCK-C mRNA precedes increased PEPCK activity by 2 to $3 \mathrm{~h}$, and maximal PEPCK activity is observed with a 4-h exposure to glucagon (Christ et al., 1988). Similarly, PEPCK activity may be decreased rapidly because of a half-life of only $2.3 \mathrm{~h}$, which is accelerated greatly by insulin (Christ et al., 1990). The timing of sample collection, relative to glucagon injection, might have masked our ability to detect changes in PEPCK-C mRNA or PEPCK activity. Previous research indicates a reduction in PEPCK mRNA with short-term glucagon infusion that reflects a response to increased circulating insulin concentrations (She et al., 1999). The lack of marked response to glucagon for PEPCK mRNA coupled with a lack of change in blood insulin concentrations suggests that PEPCK mRNA is either unresponsive to glucagon in midlactation cows or is maximally expressed under the experimental conditions utilized. Additional research that evaluates glucagon responsiveness across a spectrum of physiological states is necessary to determine the role of glucagon and other factors in regulating PEPCK in bovine.

Analysis of total PC protein abundance by immunoblotting for biotin-binding enzymes revealed a lack of effect of glucagon treatment on the relative amount of PC protein. This immunoblotting procedure detected a $146.2-\mathrm{kDa}$ band and a $104.2-\mathrm{kDa}$ band in the bovine liver that contains a biotin-binding region (Figure 4). Purified bovine PC standard is identified as a singly stained band at $137.5 \mathrm{kDa}$. There are 4 known biotindependent enzymes that are expressed in mammals: PC, acetyl-CoA carboxylase, propionyl-CoA carboxyl- ase, and 3-methylcrotonyl-CoA carboxylase. The structure of PC consists of 4 identical subunits that are approximately 120 to $130 \mathrm{kDa}$ each (Wallace and Easterbrook-Smith, 1985). The molecular weight of propionylCoA carboxylase is $75 \mathrm{kDa}$, and that of 3-methylcrotonyl-CoA carboxylase is $72 \mathrm{kDa}$ (Salto et al., 1999). Acetyl-CoA carboxylase is the largest biotin-dependent carboxylase with a molecular weight of approximately 220 $\mathrm{kDa}$ (Haneji and Koide, 1989). By using these values and the molecular weight of bovine PC standard and given the resolving power of our PAGE analysis, we conclude that the band staining at $146.2 \mathrm{kDa}$ is bovine PC. At present, it cannot be determined whether the $104.2-\mathrm{kDa}$ band is propionyl-CoA carboxylase or 3methylcrotonyl-CoA carboxylase. Previous work with rats has shown that 3-methylcrotonyl-CoA carboxylase is the most abundant biotin enzyme, and propionylCoA carboxylase is the least abundant (Salto et al., 1999). Regardless, the present analysis can be used to determine the relative abundance of $\mathrm{PC}$ in bovine liver samples, but additional optimization is necessary to determine the abundance of other biotin-binding proteins in bovine liver.

Pearson correlation coefficients for PC mRNA and protein abundance in saline-treated cows is $0.91(P<$ $0.05 ; \mathrm{n}=8)$ for mRNA, enzyme activity is $0.79(P<0.12$; $\mathrm{n}=8$ ), and for protein abundance and enzyme activity is $0.91(P<0.05 ; \mathrm{n}=8)$. Together, these data indicate that PC mRNA expression mirrors that of PC activity and protein abundance. These data confirm previous observations with regard to PC mRNA and PC activity (Greenfield et al., 2000; Hammon et al., 2003) and extend these data to include a relationship between the relative abundance of biotin-bound PC enzyme and PC mRNA or PC activity. A similar relationship has been observed in nonruminants (Rathman et al., 2003).

Glucagon did not affect the conversion of propionate or lactate to glucose (Table 4). Previous data indicate 


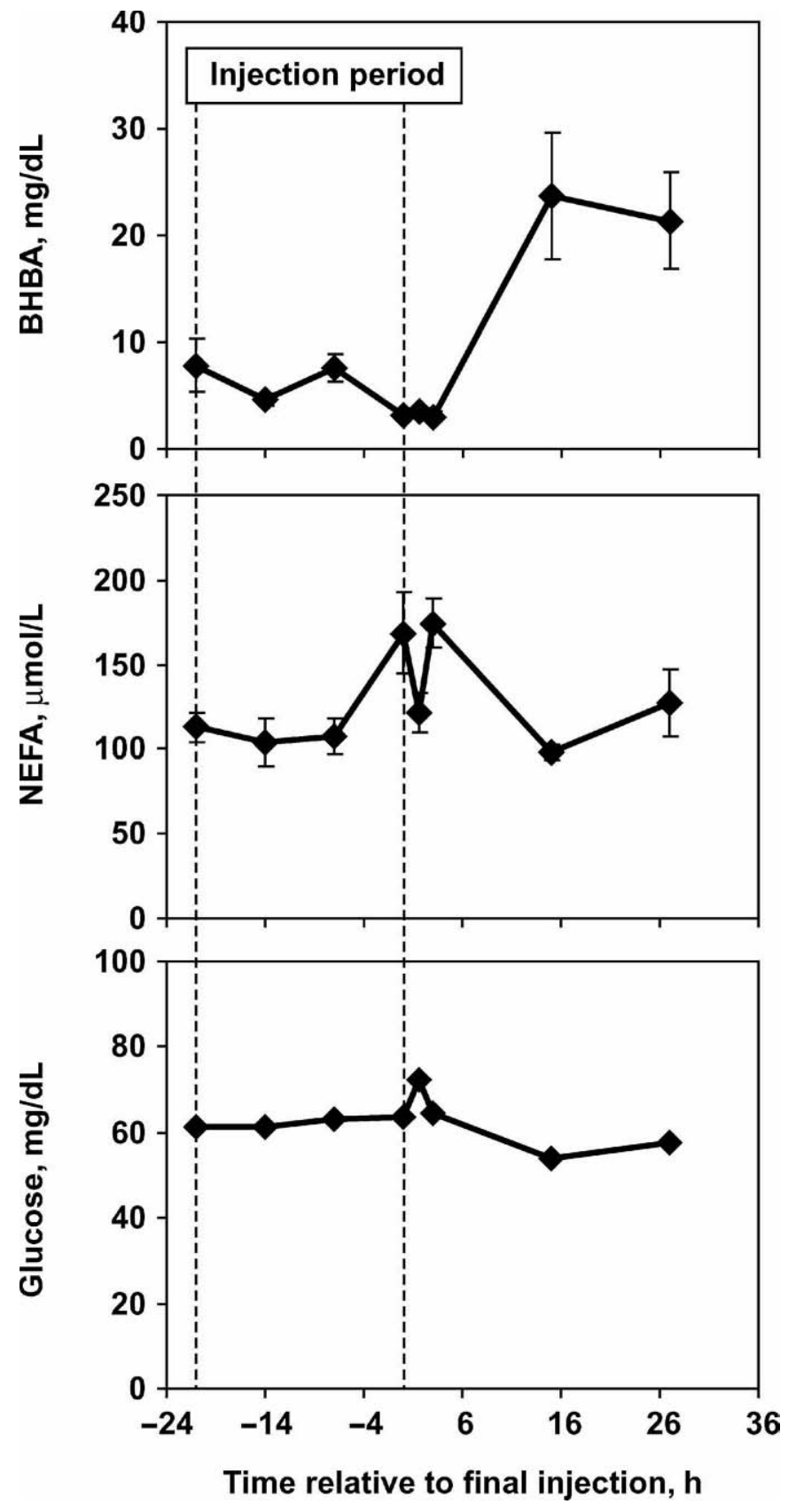

Figure 3. Profile of plasma BHBA, NEFA, and glucose concentrations as a fraction of time during saline and glucagon injections. Cows were injected subcutaneously with glucagon or saline at $-21,-14$, -7 , and $0 \mathrm{~h}$. Blood samples were obtained at $-21,-14,-7,0,3$, and $27 \mathrm{~h}$ relative to time of final injections. Plasma BHBA, NEFA, and glucose concentrations were responsive $(P<0.05)$ to time relative to final injection, but there was no effect of glucagon $(P>0.05)$ or time $\times$ treatment effects $(P>0.05)$. Data are least squares means and standard errors for the main effect of time relative to final injections (glucagon and saline combined).

a direct effect of glucagon to increase gluconeogenesis from propionate in bovine hepatocytes (Donkin and Armentano, 1995). For glucagon-treated cows, the rela-
Table 4. Effect of glucagon administration on gluconeogenesis in liver slices, hepatic enzyme activities, and abundance of biotin-binding proteins $^{1}$

\begin{tabular}{|c|c|c|c|}
\hline \multirow[b]{2}{*}{ Variable } & \multicolumn{2}{|c|}{ Treatment ${ }^{1}$} & \multirow[b]{2}{*}{$P$} \\
\hline & Saline & Glucagon & \\
\hline \multicolumn{4}{|c|}{ mRNA abundance ${ }^{2}$} \\
\hline PEPCK-C & $4.68 \pm 0.96$ & $6.78 \pm 0.96$ & $<0.15$ \\
\hline PEPCK-M & $1.02 \pm 0.25$ & $1.49 \pm 0.25$ & NS \\
\hline $\mathrm{PC}$ & $0.62 \pm 0.28$ & $0.98 \pm 0.28$ & NS \\
\hline \multicolumn{4}{|c|}{ Protein abundance ${ }^{3}$} \\
\hline $\mathrm{PC}$ & $2.60 \pm 0.42$ & $2.61 \pm 0.42$ & NS \\
\hline PCC & $1.69 \pm 0.11$ & $1.74 \pm 0.10$ & NS \\
\hline \multicolumn{4}{|c|}{ Enzyme activity ${ }^{4}$} \\
\hline $\mathrm{PC}$ & $28.5 \pm 11.4$ & $35.0 \pm 11.4$ & NS \\
\hline PEPCK & $31.1 \pm 4.8$ & $30.3 \pm 4.8$ & NS \\
\hline \multicolumn{4}{|c|}{ Substrate conversion to glucose $\mathrm{e}^{5}$} \\
\hline Propionate & $2.65 \pm 0.47$ & $3.37 \pm 0.50$ & NS \\
\hline Lactate & $0.50 \pm 0.09$ & $0.64 \pm 0.09$ & NS \\
\hline
\end{tabular}

${ }^{1}$ Cows were injected subcutaneously at $-21,-14,-7$, and $0 \mathrm{~h}$ with either $3.75 \mathrm{mg}$ of bovine glucagon $(15 \mathrm{mg} / \mathrm{d})$ or saline $(\mathrm{n}=8$ per treatment). Liver biopsy samples were obtained within $3 \mathrm{~h}$ after the last glucagon or saline injection and were analyzed for pyruvate carboxylase (PC) and PEPCK mRNA abundance and activity, PC and propionyl CoA carboxylase (PCC) protein abundance, and the rates of lactate and propionate metabolism to glucose.

${ }^{2}$ Arbitrary units of mRNA.

${ }^{3}$ Arbitrary units of biotin-binding protein.

${ }^{4}$ Measured as nmol of reaction product formed $/ \mathrm{mg}$ of protein per $\min$

${ }^{5}$ Measured as nmol of precursor converted to glucose/mg of wet tissue per $\mathrm{h}$.

tionship between $\mathrm{PC}$ mRNA and $\mathrm{PC}$ protein abundance is diminished with a Pearson coefficient of $0.42(P<$ $0.10 ; \mathrm{n}=8$ ) in those animals, and there is a lack of correlation for PC mRNA and enzyme activity for those cows. In vitro experiments have demonstrated an effect of propionate to inhibit synthesis of glucose from lactate (Blair et al., 1973; Anderson and Bridges, 1984). Methylmalonyl-CoA, an intermediate in the metabolism of propionate to succinate, allosterically inhibits PC activity (Smith and Osborne-White, 1971). From these data, we propose that an increase in propionate use with glucagon treatment in midlactation cows leads to the inhibition of lactate utilization through an allosteric inhibition of PC activity.

\section{CONCLUSIONS}

Results of this study indicate a lack of effect of glucagon on PC and PEPCK activities when glucagon is administered subcutaneously over a 21-h period. Exogenous glucagon but did not change PEPCK-C, PEPCK$\mathrm{M}$, or PC mRNA expression. Pyruvate carboxylase and PEPCK activities and PC protein abundance were not affected by the glucagon treatment. Despite a lack of 


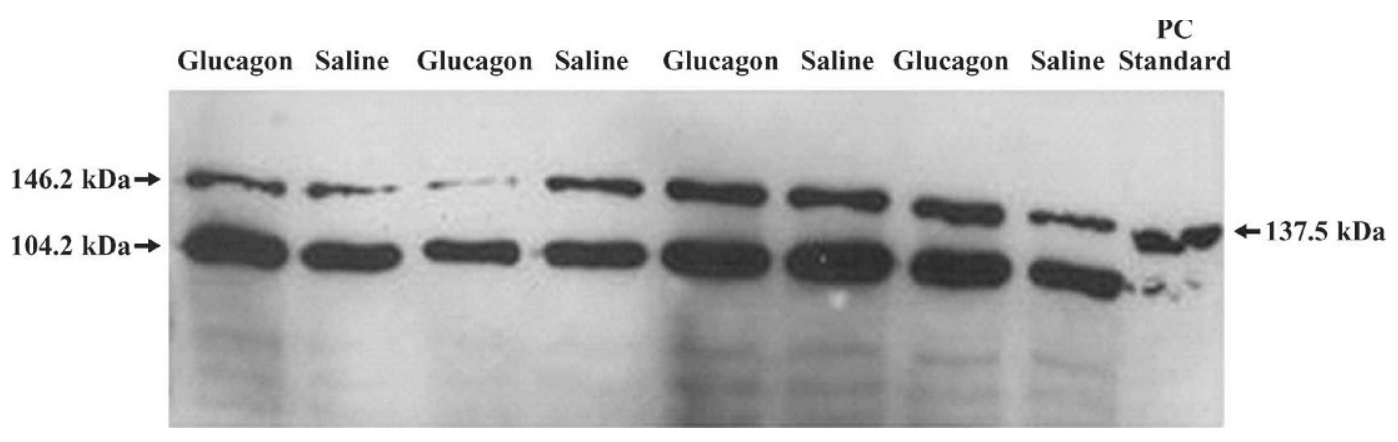

Figure 4. Profile of biotinylated proteins in liver of 8 of 16 cows receiving glucagon or saline injections. Cows were injected with 15 mg of glucagon given at $-21,-14,-7$, and $0 \mathrm{~h}$ relative to last injection, and liver biopsy samples were obtained at $+3 \mathrm{~h}$ relative to final injection. Protein was extracted, and $15 \mu \mathrm{g}$ of protein were separated by using PAGE and probed for biotinylated proteins. Purified bovine PC (pyruvate carboxylase; far right lane) was used to verify PC detection.

response of enzymes to glucagon, blood glucagon concentration was elevated in cows receiving glucagon treatment. However, the in vitro rates of gluconeogenesis from propionate and lactate were not affected by glucagon treatment.

\section{REFERENCES}

Agca, C., R. B. Greenfield, J. R. Hartwell, and S. S. Donkin. 2002. Cloning and characterization of bovine cytosolic and mitochondrial PEPCK during transition to lactation. Physiol. Genomics 11:53-63.

Aiello, R. J., and L. E. Armentano. 1987. Gluconeogenesis in goat hepatocytes is affected by calcium, ammonia and other key metabolites but not primarily through cytosolic redox state. Comp. Biochem. Physiol. 88B:193-201.

Anderson, J. W., and S. R. Bridges. 1984. Short-chain fatty acid fermentation products of plant fiber affect glucose metabolism of isolated rat hepatocytes. Proc. Soc. Exp. Biol. Med. 177:372-376.

Beale, E., T. Andreone, S. Koch, M. Granner, and D. Granner. 1984. Insulin and glucagon regulates cytosolic phosphoenolpyruvate carboxykinase (GTP) mRNA in rat liver. Diabetes 33:328-332.

Bell, A. W. 1995. Regulation of organic nutrient metabolism during transition from late pregnancy to early lactation. J. Anim. Sci. 73:2804-2819.

Blair, J. B., D. E. Cook, and H. A. Lardy. 1973. Interaction of propionate and lactate in the perfused rat liver. J. Biol. Chem. 248:3608-3614.

Bobe, G., B. N. Ametaj, J. W. Young, and D. C. Beitz. 2003a. Potential treatment of fatty liver with 14-day subcutaneous injections of glucagon. J. Dairy Sci. 86:3138-3147.

Bobe, G., R. N. Sonon, B. N. Ametaj, J. W. Young, and D. C. Beitz. 2003b. Metabolic responses of lactating dairy cows to single and multiple subcutaneous injections of glucagon. J. Dairy Sci. 86:2072-2081.

Brockman, R. P., and J. G. Manns. 1974. Effects of glucagon on activities of hepatic enzymes in sheep. Cornell Vet. 64:217-224.

Burcelin, R., E. B. Katz, and M. J. 1996. Molecular and cellular aspects of the glucagon receptor: Role in diabetes and metabolism. Diabetes Metab. 22:373-396.

Chomczynski, P. N., and N. Sacchi. 1987. Single-step method of RNA isolation by acid guanidinium thiocyanate-phenol-choloroform extraction. Anal. Biochem. 162:156-167.

Christ, B., A. Nath, H. Bastian, and K. Jungermann. 1988. Regulation of the expression of the phosphoenolpyruvate carboxykinase gene in cultured rat hepatocytes by glucagon and insulin. Eur. J. Biochem. 178:373-379.
Christ, B., A. Nath, and K. Jungermann. 1990. Mechanism of the inhibition by insulin of the glucagon-dependent activation of the phosphoenolpyruvate carboxykinase gene in rat hepatocytes cultures. Action on gene transcription, mRNA level and stability as well as hysteresis effect. Biol. Chem. Hoppe-Seyler 371:395-402.

Christophe, J. 1995. Glucagon and its receptor in various tissues. Ann. N. Y. Acad. Sci. 805:31-43.

Cryer, P. E., S. N. Davis, and H. Shamoon. 2003. Hypoglycemia in diabetes. Diabetes Care 6:1902-1912.

de Boer, G., A. Trenkle, and J. W. Young. 1986. Secretion and clearance rates of glucagon in dairy cows. J. Dairy Sci. 69:721-733.

Donkin, S. S., and L. E. Armentano. 1993. Preparation of extended in vitro cultures of bovine hepatocytes that are hormonally responsive. J. Anim. Sci. 71:2218-2227.

Donkin, S. S., and L. E. Armentano. 1995. Insulin and glucagon regulation of gluconeogenesis in preruminating and ruminating bovine. J. Anim. Sci. 73:546-551.

Gibbard, S., and P. J. Watkins. 1968. A micro-method for the enzymatic determination of $\mathrm{D}$ - $\beta$-hydroxybutyrate and acetoacetate. Clin. Chim. Acta 19:511-521.

Greenfield, R. B., M. J. Cecava, and S. S. Donkin. 2000. Changes in mRNA expression for gluconeogenic enzymes in liver of dairy cattle during transition to lactation. J. Dairy Sci. 83:1228-1236.

Hammon, H. M., S. N. Sauter, M. Reist, Y. Zbinden, C. Philipona, C. Morel, and J. W. Blum. 2003. Dexamethasone and colostrum feeding affect hepatic gluconeogenic enzymes differently in neonatal calves. J. Anim. Sci. 81:3095-3106.

Haneji, T., and S. S. Koide. 1989. Transblot identification of biotincontaining proteins in rat liver. Anal. Biochem. 177:57-61.

Hanson, R. W., and Y. M. Patel. 1994. Phospoenolpyruvate carboxykinase (GTP): The gene and the enzyme. Adv. Enzymol. Relat. Areas Mol. Biol. 69:203-281.

Hanson, R. W., and L. Reshef. 1997. Regulation of phosphoenolpyruvate carboxykinase (GTP) gene expression. Annu. Rev. Biochem. 66:581-611.

Hartwell, J. R., M. J. Cecava, B. Miller, and S. S. Donkin. 1999. Rumen protected choline and dietary protein for transition cows. J. Dairy Sci. 82(Suppl. 1):125. (Abstr.)

Hippen, A. R., P. She, J. W. Young, D. C. Beitz, G. L. Lindberg, L. F. Richardson, and R. W. Tucker. 1999a. Metabolic responses of dairy cows and heifers to various intravenous dosages of glucagon. J. Dairy Sci. 82:1128-1138.

Hippen, A. R., P. She, J. W. Young, D. C. Beitz, G. L. Lindberg, L. F. Richardson, and R. W. Tucker. 1999b. Alleviation of fatty liver in dairy cows with 14-day intravenous infusions of glucagon. J. Dairy Sci. 82:1139-1152.

Iynedjian, P. B., and R. W. Hanson. 1977. Increase in level of functional messenger RNA coding for phosphoenolpyruvate carboxykinase (GTP) during induction by cyclic adenosine $3^{\prime}: 5^{\prime}$-monophosphate. J. Biol. Chem. 252:655-662. 
Jiang, G., and B. B. Zhang. 2003. Glucagon and regulation of glucose metabolism. Am. J. Physiol. Endocrinol. Metab. 284:E671-E678.

Johnson, M. M., and J. P. Peters. 1993. Technical note: An improved method to quantify nonesterified fatty acids in bovine plasma. J. Anim. Sci. 71:753-756.

Komjati, M., P. Bratusch-Marrain, and W. Waldhausl. 1986. Superior efficacy of pulsatile versus continuous hormone exposure on hepatic glucose production in vitro. Endocrinology 118:312-319.

Laemmli, U. K. 1970. Cleavage of structural proteins during the assembly of the head of bacteriophage T4. Nature 227:680-685.

Liu, J. S., E. A. Park, A. L. Gurney, W. J. Roesler, and R. W. Hanson. 1991. Cyclic AMP induction of phosphoenolpyruvate carboxykinase (GTP) gene transcription is mediated by multiple promoter elements. J. Biol. Chem. 266:19095-19102.

Rathman, S. C., R. K. Blanchard, L. Badinga, J. F. Gregory, III., S. Eisenschenk, and R. J. McMahon. 2003. Dietary carbamazepine administration decreases liver pyruvate carboxylase activity and biotinylation by decreasing protein and mRNA expression in rats. J. Nutr. 133:2119-2124.

Rizza, R. A., and J. E. Gerich. 1979. Persistent effect of sustained hyperglucagonemia on glucose production in man. J. Clin. Endocrinol. Metab. 48:352-355.
Salto, R., M. D. Giron, M. del Mar Sola, and A. B. Vargas. 1999. Evolution of pyruvate carboxylase and other biotin-containing enzymes in developing rat liver and kidney. Mol. Cell. Biol. 200:111-117.

SAS Institute. 1988. SAS Users Guide: Statistics. Release 6.03 ed. SAS Inst., Inc., Cary, NC.

Savon, S., P. Hakimi, and R. Hanson. 1993. Expression of the genes for the mitochondrial and cytosolic forms of phosphoenolpyruvate carboxykinase in avian liver during development. Biol. Neonate 64:62-68.

She, P., G. L. Linberg, A. R. Hippen, D. C. Beitz, and J. W. Young. 1999. Regulation of messenger ribonucleic acid expression for gluconeogenic enzymes during glucagon infusions into lactating cows. J. Dairy Sci. 82:1153-1163.

Smith, R. M., and W. S. Osborne-White. 1971. Synthesis of phosphoenolpyruvate from propionate in sheep liver. Biochem. J. 124:867-876.

Vazquez-Anon, M., S. Bertics, M. Luck, R. R. Grummer, and J. Pinheiro. 1994. Peripartum liver triglyceride and plasma metabolites in dairy cows. J. Dairy Sci. 77:1521-1528.

Wallace, J. C., and S. B. Easterbrook-Smith. 1985. Pyruvate carboxylase. Pages 66-108 in CRC Series in Enzyme Biology. D. B. Keech and J. C. Wallace, ed. CRC Press, Boca Raton, FL. 